WellBeing International

WBI Studies Repository

$1-2007$

\title{
Physiology, Propaganda, and Pound Animals: Medical Research and Animal Welfare in Mid-Twentieth Century America
}

John Parascandola

Follow this and additional works at: https://www.wellbeingintlstudiesrepository.org/oppares

Part of the Animal Experimentation and Research Commons, Animal Studies Commons, and the Politics and Social Change Commons

\section{Recommended Citation}

Parascandola, J. (2007). Physiology, propaganda, and pound animals: Medical research and animal welfare in mid-twentieth century america. Journal of the history of medicine and allied sciences, 62(3), 277-315.

This material is brought to you for free and open access by WellBeing International. It has been accepted for inclusion by an authorized administrator of the WBI Studies Repository. For more information, please contact wbisr-info@wellbeingintl.org.

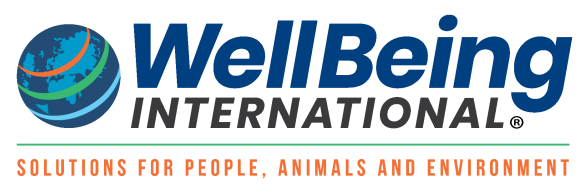




\title{
Physiology, Propaganda, and Pound Animals: Medical Research and Animal Welfare in Mid-Twentieth Century America
}

John Parascandola

\begin{abstract}
In 1952, the University of Michigan physiologist Robert Gesell shocked his colleagues at the business meeting of the American Physiological Society by reading a prepared statement in which he claimed that some of the animal experimentation being carried out by scientists was inhumane. He especially attacked the National Society for Medical Research (NSMR), an organization that had been founded to defend animal experimentation. This incident was part of a broader struggle taking place at the time between scientists and animal welfare advocates with respect to what restrictions, if any, should be placed on animal research. A particularly controversial issue was whether or not pound animals should be made available to laboratories for research. Two of the prominent players in this controversy were the NSMR and the Animal Welfare Institute, founded and run by Gesell's daughter, Christine Stevens. This article focuses on the interaction between these two organizations within the broader context of the debate over animal experimentation in the mid-twentieth century.
\end{abstract}

\section{KEYWORDS}

physiology, animal research, animal welfare, antivivisection, National Society for Medical Research, Animal Welfare Institute, American Physiological Society, Robert Gesell, Christine Stevens, Ralph Rohweder

On 15 April 1952, prominent physiologist Robert Gesell shocked his colleagues at the business meeting of the American Physiological Society by reading a prepared statement in which he proclaimed that some of the animal experimentation being carried out by scientists was inhumane, in fact, "a travesty of humanity." He especially attacked the National Society of Medical Research, an organization formed largely to defend animal experimentation, for its efforts "to provide an inexhaustible number of animals to an ever growing crowd of career scientists with but little biological background and scant interest in the 
future of man." Such a vehement assault by a member of the fraternity of physiologists on the way in which animals were used in research was probably unprecedented in the history of the Society. The fact that Gesell was Chair of the prestigious Department of Physiology at the University of Michigan undoubtedly made the matter worse in the eyes of his colleagues. ${ }^{1}$

This incident was part of a broader struggle taking place at the time between scientists and animal advocates with respect to what restrictions, if any, should be placed on animal research. An issue of particular concern was the right of laboratories to claim animals in pounds or shelters for research, a subject that is the major focus of this article. Two of the prominent players in this controversy were the earlier-mentioned National Society for Medical Research (NSMR) and the Animal Welfare Institute, an organization founded and run by Gesell's daughter, Christine Stevens. This article deals with the interaction between those two organizations within the broader context of the debate over animal experimentation in the mid-twentieth century.

\section{FOUNDING OF THE NSMR}

As Susan Lederer has pointed out, the claim by William Welch of the John Hopkins University in 1926 that by then antivivisection was a "lost cause" was an exaggeration of the actual situation. Lederer notes that American antivivisectionists continued to exert pressure on the research community, waging a continuous campaign in the 1930s and 1940s to try to enact legislation prohibiting experimentation with living dogs. She admits, however, that antivivisection no longer commanded the broad public support that it did in the late nineteenth century. Consequently these bills routinely failed to pass. Bernard Unti argues that the antivivisection movement, although not dead, was certainly not robust between 1920 and 1950. He cites as evidence the facts that the dog exemption bills never "made it out of committee, nor did they generate great alarm on the part of experimenters." ${ }^{2}$

Unti and Lederer also recognize that concerns about animal experimentation were not limited to antivivisectionists who wished to abolish the practice. There were also animal advocates who accepted vivisection as a necessity, but sought to reform and regulate it. Groups such as the Society for the Prevention of Abuse in Animal Experimentation and the American Society for the Prevention of Cruelty to Animals advocated the regulation of vivisection in the early part of the twentieth century. The latter organization, however, withdrew from the issue around 1912 and the former society disbanded several years later. Efforts to regulate the use of animals in research were no more successful than those to abolish it. ${ }^{3}$

The conflict between animal advocates and scientists became more intense again around the mid-point of the twentieth century. A major issue fueling the controversy was the question of the provision of animals

\footnotetext{
${ }^{1}$ Robert Gesell to members of the Federation of American Societies for Experimental Biology (FASEB), 10 March 1953, Gesell file, Animal Welfare Institute Files, Washington, DC (hereafter referred to as AWI Files). At the time that I did this research, these files were at the AWI's headquarters in Washington, DC. The AWI records have since been deposited in the North Carolina State University Libraries' Special Collections Research Center in Raleigh, NC. See also John R. Brobeck, Orr E. Reynolds, and Toby A. Appel, History of the American Physiological Society: The First Century, 1887-1987 (Bethesda, MD: American Physiological Society, 1987), 119. The American Physiological Society was a constituent society of FASEB.

${ }^{2}$ Susan E. Lederer, "Political Animals: The Shaping of Biomedical Research Literature in Twentieth-Century America," Isis, 1992, 83, 61-79; Bernard O. Unti, “The Quality of Mercy: Organized Animal Protection in the United States 1866-1930” (Ph.D. diss., American University, 2002), 654.

${ }^{3}$ Unti, "Quality of Mercy," 616-48; Susan E. Lederer, Subjected to Science: Human Experimentation in America before the Second World War (Baltimore, Md.: Johns Hopkins University Press, 1994), 34-35.
} 
for research by animal pounds or shelters. The support for biomedical research by the federal government expanded dramatically in the years following World War II. The passage of the Public Health Service Act of 1944 provided the legislative basis for the growth in research funding through the National Institutes of Health, from $\$ 0.7$ million in 1945 to $\$ 98$ million in 1956 . The rapid expansion of biomedical research stimulated by this funding boom led to a greatly increased demand for research animals. Pound animals had long been one source of supply for investigators, but the burst in research activity after World War II significantly increased the importance of the pound as a source of inexpensive animals. ${ }^{4}$ In 1948, two prominent American physiologists noted that:

Almost one third of the nation's medical schools are supplied with experimental dogs from public pounds or from humane society operated pounds. This arrangement protects the pet owner who need have no fear of unscrupulous dog dealers. This arrangement stretches the research dollar. And this arrangement expedites teaching and research by insuring both a better supply of animals and relative freedom from antivivisectionist obstruction. ${ }^{5}$

On the eve of this burgeoning of research, biomedical scientists were already becoming concerned about the activities of various antivivisectionist and humane societies. Laws to restrict medical research, especially research on dogs, had been introduced in legislative bodies in a number of states. The scientific community, alarmed by what it believed as a threat to biomedical research, saw a need to educate the public about the importance of animal experimentation. At the 1944 meeting of the Association of American Medical Colleges in Detroit, a special committee was appointed to consider the sponsorship by the Association of an organization to conduct a national educational campaign on the subject of the necessity and contributions of animal experimentation. The committee recommended, and the Association approved at its 1945 meeting, that the Association sponsor a national commission for the protection of medical science. The Association's executive council appointed a board of directors for the Commission, with Anton J. Carlson of the University of Chicago as Chairman and Andrew C. Ivy of the Northwestern University as secretary-treasurer. ${ }^{6}$

Carlson, a native of Sweden, who had immigrated to the United States in 1891, was a prominent physiologist and also an ardent civil libertarian. For example, he was active in the Association for the Protection of the Foreign Born and was a sponsor of the Humanist Manifesto of the American Humanist Association. Carlson was also the first recipient of the American Humanist Association's Humanist of the Year award in 1953. He received his Ph.D. in physiology at Stanford in 1902 and had joined the faculty at the University of Chicago, where he spent the rest of his career, in 1904. Carlson frequently served as an expert witness for the Food and Drug Administration in their prosecution of cases involving adulteration and misbranding of foods and drugs. He was also known for his aggressive method of criticism of papers

\footnotetext{
${ }^{4}$ Andrew N. Rowan, Of Mice, Models, and Men: A Critical Evaluation of Animal Research (Albany: State University of New York Press, 1984), 51-53, 150-51; Margaret Morrison, "Legislation and Practice in the United States," in Animals in Research: New Perspectives in Animal Experimentation, ed. David Sperlinger (Chichester and New York: John Wiley and Sons, 1981), 6378.

${ }^{5}$ A. J. Carlson and A. C. Ivy to Deans of Medical Schools and others, 26 October 1948, Box 39, National Society for Medical Research Papers, History of Medicine Division, National Library of Medicine, Bethesda, MD (hereafter referred to as "NSMR Papers").

${ }^{6}$ Report of Secretary-Treasurer, National Commission for the Protection of Medical Science, n.d. (probably February 1946), Box 1, NSMR Papers; Thomas S. Grafton, "The Founding and Early History of the National Society for Medical Research," Lab. Anim. Sci., 1980, 30, 759-64; Maurice B. Visscher, “A Half Century in Science and Society,” Annu. Rev. Physiol., 1969, 31, 118.
} 
at scientific meetings. He enjoyed combat in support of what he considered to be a worthy cause, including the battle against antivivisection. ${ }^{7}$

Ivy, a Missouri native, obtained his doctorate in physiology under Carlson at the University of Chicago in 1918. He also earned an M.D. degree from the Rush Medical School in 1922. After teaching appointments at the Loyola University and at Chicago, Ivy became the Chair of physiology and pharmacology at the Northwestern University, where he was located at the time of the founding of the NSMR. Shortly thereafter, he became Vice President of the University of Illinois in charge of the professional colleges, including the medical school, in Chicago. Although a distinguished gastric physiologist, Ivy is perhaps best remembered by many because of his unfortunate involvement with the purported anticancer drug krebiozen in the 1950s. The Food and Drug Administration actually brought charges against Ivy in 1965 for attempting to defraud the public with krebiozen, but he was acquitted and seems to have sincerely believed in the efficacy of the drug. Like Carlson, Ivy was an activist in various humanitarian causes. For example, he was a prime mover in organizations devoted to the eradication of tuberculosis, the prevention and treatment of alcoholism, and the elimination of discrimination in higher education. He was also a consultant at the Nuremberg Tribunal on War Crimes and played a role in the formulation of a code of ethics for human experimentation. ${ }^{8}$

As the new national society was being organized, there was considerable discussion about the best name for it. "The National Commission for the Protection of Medical Science" does not seem to have been very popular with the members of the board of directors. Objections were raised to this name "as being too long, cumbersome, academic, and as having little publicity appeal and as implying that medical science needs protection for reasons other than antivivisection." Terms such as "Friends," "Protectors," and "Patrons" were rejected by the majority of the members because they were "felt to possess undesirable depreciatory implications." Carlson and Ivy also thought that a commission or society for the protection of medical research would be a "more factual and virile" name than a Friends group. In the end, the board settled on the National Society for Medical Research. The statement of purpose adopted for the Society was as follows: "To inform the public regarding the necessity, humane character and accomplishments of animal experimentation."

Carlson and Ivy, who were both based in the Chicago area, pointed out the advantage of having the central office of the organization located in Chicago because the city was the headquarters of both the Association of American Medical Colleges (the Society's original sponsor) and the American Medical Association. Chicago was made the headquarters of the Society, which was incorporated as a nonprofit organization in the state of Illinois, and Carlson was elected the first president of the group. ${ }^{10}$

Initially, the organization solicited funds to support its operating expenses from medical schools, but soon professional biomedical associations and pharmaceutical manufacturers were also asked to support the

\footnotetext{
${ }^{7}$ For biographical information on Carlson, see Maurice B. Visscher, "Carlson, Anton Julius," in Dictionary of Scientific Biography, ed. Charles Coulston Gillespie (New York: Charles Scribner's Sons, 1971), 3: 68-70; Dwight J. Ingle, “Anton J. Carlson: A Biographical Sketch," Perspect. Biol. Med., 1979, 22, S114-S136; James Harvey Young, “Anton J. Carlson: Witness for the Prosecution,” Pharm. Hist., 1999, 41, 47-51; A. C. Ivy, “Anton Julius Carlson,” Physiologist, 1959, 2, 33-39.

${ }^{8}$ For biographical information on Ivy, see Morton I. Grossman, “Andrew Conway Ivy (1893-1978),” Physiologist, 1978, 21, 1112; Patricia Spain Ward, “'Who Will Bell the Cat?’ Andrew C. Ivy and Krebiozen,” Bull. Hist. Med., 1984, 58, $28-52$.

${ }^{9}$ Minutes of the meeting of Temporary Organizing Board, National Commission for the Protection of Medical Research, 11 February 1946, box 1, NSMR Papers; A. J. Carlson and A. C. Ivy to Members of Temporary Organizing Board of Directors, 26 December 1945, Box 1, NSMR Papers.

${ }^{10}$ Minutes of the meeting of Temporary Organizing Board, 11 February 1946;Grafton, "Founding and Early History," 761.
} 
group. With some funding in hand and a decision made about a headquarters city, the Society's executive committee turned next to the question of hiring an executive secretary to administer operations. Ideally, the person selected for this position should be a science writer and a public relations expert. At a meeting of the executive committee in Chicago on 4 April 1946, Ralph A. Rohweder, representing the National Safety Council, discussed the relationship of the Council with the new Society. The members of the executive committee were apparently impressed by Rohweder's presentation and decided that he was the type of person needed for the executive secretary position. Ivy was appointed to interview Rohweder, who accepted the job at an annual salary of $\$ 6,000$ commencing 16 May. ${ }^{11}$ (By comparison, the average annual salary of professional and scientific employees in the federal service in 1947 was $\$ 4,814$. $)^{12}$

Rohweder was a public relations specialist, who had been serving as a consultant and editor for the National Safety Council for three years, at the time he was hired by the NSMR. He was also then the president of the Junior Association of Commerce of Chicago. Previously, he had been employed as assistant executive secretary of the Minnesota Safety Council. Although experienced in public safety, Rohweder apparently had no prior employment related to biomedical research. The Society also hired a combination secretary and writer and decided to recruit a person with press experience. ${ }^{13}$

By the time that the Society published its first annual report in October 1947, it was supported by 226 member organizations, ranging from medical and dental schools to professional societies in the health field to the American Red Cross. During its first year, the Society published pamphlets, established a periodical (Bulletin of the National Society for Medical Research), prepared a weekly fifteen-minute radio broadcast "presenting interesting anecdotes from research laboratories," encouraged articles on the importance of animal research, developed an exhibit, solicited the support of pharmaceutical companies, and assisted medical groups concerned with legislation on animal experimentation. ${ }^{14}$

Whatever views Rohweder may have held concerning animal experimentation before he joined the NSMR, he naturally became a strong advocate of the practice in his role as the Society's executive secretary. Before long, he had formed an opinion of antivivisectionists as irrational fanatics. When Ivy was to address the Chicago Junior Association of Commerce and Industry in 1949, Rohweder advised him that almost all "Jaycees" were contemptuous of antivivisection and therefore Ivy should not say anything to imply "that any Jaycee is such a jerk as to be an antivivisectionist." Yet, he added, Ivy should try to convince the Jaycees that "the silly AV cult" is a real public problem. ${ }^{15}$

\section{GESELL AND ANIMALS IN RESEARCH}

During the same period that the NSMR was being established and getting its program off the ground, Gesell and his daughter Christine were becoming very involved in issues of animal welfare. A native of Wisconsin, Gesell had obtained his M.D. degree from Washington University in St. Louis in 1914, while also serving as an assistant to the noted professor of physiology, Joseph Erlanger. Gesell taught physiology at the Washington University and at the University of California before accepting an offer in 1923 to head the Department of Physiology at the University of Michigan. His research interests included

\footnotetext{
${ }^{11}$ Minutes of the meeting of Temporary Organizing Board, 11 February 1946 and minutes of meetings of Executive Committee, 4 April and 20 May 1946, Box 1, NSMR Papers.

${ }^{12}$ Statistical Abstracts of the United States 1950, 71st ed. (Washington, DC: Department of Commerce, 1950), 197.

${ }^{13}$ A. J. Carlson and A. C. Ivy to Members of the Board of Directors, NSMR, 28 May 1946, Box 1, NSMR Papers.

14 "First Annual Report of the National Society for Medical Research to the Association of American Medical Colleges," October 1947, Box 1, NSMR Papers.

${ }^{15}$ Ralph A. Rohweder to A. C. Ivy, 8 September 1949, Box 5, NSMR Papers.
} 
the relation between blood flow and tissue function, and the physiology of respiration. Gesell also possessed a talent for developing instruments to measure important physiological variables. ${ }^{16}$

Gesell's graduate student and later colleague at Michigan, John Bean, who first met Gesell in 1925, offered the following description of the man:

I think Dr. Gesell was a man of rather fixed opinion, not given to compromise. He was a large, rather heavy-set man with a pleasant countenance and a roundish head, topped by a thick crop of dark, seemingly unruly hair; something of a fur cap look, which in late years was graying. ${ }^{17}$

Gesell's physiological research naturally involved the use of experimental animals. He particularly used a large number of dogs for both teaching and research. These dogs were generally obtained from the pound. According to his daughter, Gesell had always been fond of animals. She said that he made efforts to improve the conditions for experimental animals used in his laboratories. ${ }^{18}$ Gesell himself described the animal quarters at Michigan in a 1930 article as follows:

The animal quarters are on the top floor. Room 65 is equipped with metal rat cages, room 66 with a bird cage 40 inches deep running the full length and height of the room, and room 67 is equipped with intercommunicating rabbit cages. The major portion of our quarters is given over to care of dogs. Virtually all of the mammalian physiology instruction and research has been done on the dog. Mindful of the fine traits of this animal and his sensitive nature we have attempted to make him as comfortable as our means would permit. To this end we have provided thirty-three small kennels with private outside runways. . . The kennels are also heated by hot-water pipes running the full length of the quarters. $A$ window and a centrally pivoted door open into the runway. The doors are operated by the dogs from either inside or outside. The runways are separated by heavy galvanized iron fencing. This arrangement has eliminated fatal encounters common to dog quarters but still offers enough communication to break the monotony. ${ }^{19}$

Gesell added that the animals and their quarters were taken care of exclusively by the laboratory helpers, "who have taken a very active interest in the proper care of the animals." ${ }^{20}$ Stevens stated in an interview in 1992 that two brothers, Albert and Homer Pepper, cared for the animals for many years and that they tried to make sure that the animals were treated well. Stevens also praised the kennel runs as giving the dogs more opportunity for exercise than they would have had in small cages. She admitted that neighbors sometimes complained about the barking and that, for a time, the dogs were debarked by having their vocal cords cut, but this practice was then abandoned. According to Stevens, the dogs were fed well with

\footnotetext{
${ }^{16}$ Horace W. Davenport, Fifty Years of Medicine at the University of Michigan, 1891-1941 (Ann Arbor: University of Michigan Medical School, 1986), 94-107.

${ }^{17}$ John W. Bean, "Reminiscences: My Entrance into Physiology," undated typescript, 7, Box 2, Department of Physiology Papers, Bentley Historical Library, University of Michigan, Ann Arbor, MI (hereafter referred to as Physiology Papers).

${ }^{18}$ Interview by John Parascandola of Christine Stevens, Washington, DC, 9 June 1992. The author has in his possession a summary of the interview.

${ }^{19}$ Robert Gesell, "Department of Physiology University of Michigan," in Methods and Problems of Medical Education, 18th series (New York: The Rockefeller Foundation, 1930), 1-16.

${ }^{20}$ Interview of Stevens.
} 
food scraps obtained from the University of Michigan Union, and they were used only in nonsurvival experiments and under anesthesia. ${ }^{21}$

A less favorable view of the dog quarters was presented by physiologist Horace Davenport, who was professor of physiology at Michigan from 1956 to 1978, in his history of the University of Michigan Medical School (1986). Unfortunately, he does not give the source of his information on this subject. Although admitting that Gesell's concern for animal welfare became stronger after World War II, Davenport described the dog quarters in earlier years as follows:

Those were the days before the advent of experts in Laboratory Animal Medicine, and the animals were cared for by untrained men. Every so often one of the dieners was sent by truck to Detroit where pound dogs were loaded, six at a time, into great iron cages to be brought back to Ann Arbor. When the dogs were loosed into their pens on the roof, each member of the staff ran to claim the best and the biggest he could, leaving those with sniffles and enteritis to die in a few days. Surviving dogs were fed garbage from local boarding houses; they were unwashed; and they stank. As the dogs ran about their open pens they barked at any provocation. Neighbors objected, and at first dogs were debarked by having their vocal cords cut. That became too much of a bother; the neighbors had to put up with the barking and the dean with the neighbors' complaints. ${ }^{22}$

In spite of the very different conclusions drawn by Stevens and Davenport, it is interesting to note that many of their facts are in agreement. Depending upon whether one describes the food provided to the animals as table scraps or as garbage, however, one's view of the adequacy of the dogs' diet may well vary. One can also interpret the abandonment of the practice of debarking the dogs as being due to humane considerations or because it was too much of a bother. It is also possible that the dog quarters did improve over time, helping to account for some of the differences in the two descriptions.

Bean confirmed that a large number of animals, especially dogs, were used for teaching and research at Michigan. He also noted, however, that Gesell made it clear that there was to be no maltreatment of the animals, either in their housing or in the experimentation. The animals were generally anesthetized with morphine followed by urethane. ${ }^{23}$ Instructions developed by Gesell in 1935 on anesthetizing animals clearly state:

No change in anaesthesia shall be made without consultation with the director of the laboratory. No animal shall be left alone, even though it appears to be thoroughly anaesthetized, for longer than a few minutes. Each worker should provide himself with an emergency supply of urethane to increase anaesthesia . . . At the close of the experiment the animals are killed by intravenous injection of alcohol. ${ }^{24}$

Bean further explained that animal quarters in many laboratories were not good at the time and that Gesell was proud of his kennels with their large runways open to the sky. When the Medical School was contemplating moving the preclinical departments to new facilities, Gesell objected because the new plans did not provide adequate runway space and the kind of housing that he wanted for the animals. ${ }^{25}$

\footnotetext{
${ }^{21}$ Interview of Stevens.

${ }^{22}$ Davenport, Fifty Years of Medicine, 97.

${ }^{23}$ John Bean, "Some Reminiscences (Continued)," undated typescript, 14, Box 2, Physiology Papers.

${ }^{24}$ [Robert Gesell], "Research Facilities in the Department of Physiology_1935," Gesell file, AWI Files.

${ }^{25}$ John Bean, "Reminiscences," undated typescript, 6-7, Box 2, Physiology Papers.
} 
Whatever one thinks of the dog quarters at Michigan, it seems clear that Gesell's concerns about animal welfare long predated his post-World War II involvement in this area. Events in the postwar period, however, precipitated a confrontation between Gesell and many of his physiology colleagues.

When the NSMR was first being established, Gesell was supportive of the organization. He helped to enlist the support of the Dean of the Michigan Medical School and the members of his own department for the new society. In his letter to Carlson of 8 February 1946, however, he also made it clear that he hoped that the proposed commission (as it was still being referred to at that time) would devote attention to the education of scientists as well as the public with respect to animal issues.

I am not one of those who believe that the conditions of animal experimentation are ideal. I believe the commission could raise the question whether the experimental animal is receiving the consideration to which he is entitled particularly as regards survival experiments in which the animal is likely to suffer. It is my experience that there are always a number of us who may be too sure of man's privileges to experiment on the lower forms. Some system of scrutinizing the soundness of biological problems and the skill and wisdom and consideration of the scientist would do much to convince the public that our minds are open to all sides of the problem. I doubt the wisdom of a policy which offers no supervision of animal experimentation whatever. The surest way of preventing interference from the outside by enactment of laws restricting experimentation is to convince the public that we ourselves see the soundness of proper supervision. Our committee should be best qualified to accept responsibility of this supervision. ${ }^{26}$

Gesell also wrote to the Chair of the Public Health Committee of the Michigan Senate in 1947 to support a bill concerning the use of animals for the advancement of medicine and public health. He added that he hoped that if the bill passed, the Chair would use his influence to see that sound rules were promulgated for animal use and that "every possible consideration is given to laboratory animals, the proper use of anaesthetics, proper care and comfortable quarters for animals before and after experimental procedures." ${ }^{27}$ By this time, he was also lecturing medical students on the proper care of laboratory animals and on the use of less sentient organisms or chemical and physical methods for obtaining biological data whenever possible. ${ }^{28}$ Gesell was advocating not only the humane treatment of animals, but also the use, where possible, of what we now call alternatives to animal experimentation, at least a decade before the publication of Russell and Burch's classic 1959 book The Principles of Humane Experimental Technique. ${ }^{29}$

\footnotetext{
${ }^{26}$ Robert Gesell to A. J. Carlson, 8 February 1946, Gesell file, AWI Files.

${ }^{27}$ Robert Gesell to Howard Estes, 1 May 1947, Box 2, Robert Gesell Papers, Bentley Historical Library, University of Michigan, Ann Arbor, MI (hereafter referred to as Gesell Papers).

${ }^{28}$ W. A. Freyburger to Theodore Cooper, 22 December 1980, Box 8, NSMR Papers; Interview of Stevens. Gesell's views on this issue are reflected in Christine Stevens, "Notes for a Prospectus for the Animal Welfare Institute," undated typescript, 3, Box 8, NMSR Papers. The prospectus advocates minimizing animal suffering in experimentation by replacing higher mammals by much lower forms of life or life in lower stages of development whenever possible, more efficient statistical design of experiments and avoidance of unnecessary repetition in order to reduce the number of animals used, and substitution of chemical and physical methods whenever possible for biological methods in experiments and tests.

${ }^{29}$ W. M. S. Russell and R. L. Burch, The Principles of Humane Experimental Technique (London: Methuen and Company, 1959). For further information on the history of the development of alternatives to animal research and testing, see John Parascandola, "Historical Perspectives on In Vitro Toxicology," Alternative Methods in Toxicology, 1991, 8, 87-96.
} 


\section{CREATION OF THE ANIMAL WELFARE INSTITUTE}

Gesell's first open conflict over the humane treatment of animals seems to have occurred in connection with the local humane society of Ann Arbor. Stevens was then serving on the board of this society. A controversy developed with the veterinarian, Dr. Shipman, who was president of the group. Shipman was using injections of strychnine to euthanize animals at the society's shelter. Gesell advised that strychnine did not produce a painless death and that the injection of nembutal would be more humane. Shipman said that he tried nembutal, but that it did not always work, which Stevens claimed was because he did not use enough of the drug. A carbon monoxide chamber was then built and offered to Shipman, but he refused it and continued to use strychnine. Eventually Stevens and her allies managed to oust the veterinarian. This incident helped Gesell and his daughter to get more involved in the area of animal welfare. $^{30}$

Through her work in the local humane society, Stevens became involved in the issue of whether or not humane societies should be forced to turn over pound animals to research institutions. The major thrust of the NSMR in its early years was to combat legislation restricting animal experimentation and to work for the passage of animal seizure or animal procurement laws. These laws required animal shelters to make available, upon request, unwanted stray animals to scientific institutions. The first such law was passed in Minnesota in 1948, and it applied to all shelters that received funds from tax revenues. In the following year, Wisconsin passed an even more comprehensive law, requiring any shelter, whether or not it received tax dollars, to surrender unwanted stray animals to scientific institutions. Procurement laws of one sort or another were passed in several other states at around this time. ${ }^{31}$

The American Humane Association (AHA), which had been founded in 1877 and served as an umbrella group for local humane societies, tried but failed to negotiate some kind of agreement with the NSMR concerning the pound seizure laws. A conflict arose in the AHA between those who wanted the Association to oppose these laws and those who believed the group should not take any action in the controversy. Eventually, this led to the dissident faction withdrawing from the AHA and forming their own organization, the Humane Society of the United States, in $1954 .^{32}$ In the meantime, however, Stevens and her husband Roger, a successful businessman in the field of real estate, offered $\$ 10,000$ to the AHA to study the problem of supplying animals to laboratories, but the organization turned down the gift. The Stevens then decided to establish their own nonprofit organization, and they founded the Animal Welfare Institute (AWI) in 1951. The new entity had its headquarters in New York, where the couple was living at the time. ${ }^{33}$ It should be noted that Roger later rose to prominence as the founding Chair of the Kennedy Center for the Performing Arts and as finance Chair for the Democratic National Committee. He was awarded the Medal of Freedom in 1988 by President Ronald Reagan. ${ }^{34}$

\footnotetext{
${ }^{30}$ Interview of Stevens; Bean, "Some Reminiscences (Continued)," 14.

${ }^{31}$ Christine Stevens, "Laboratory Animal Welfare," in Animals and Their Legal Rights: A Survey of American Laws from 1641 to 1970, ed. Emily Stewart Leavitt, 2nd ed. (Washington, DC: Animal Welfare Institute, 1970), 46-66; National Institutes of Health, Division of Research Grants, The Dog in Medical Research (Washington, DC: U.S. Department of Health, Education, and Welfare, 1953), 4-8.

${ }^{32}$ On the founding and history of the Humane Society, see Bernard Unti, Protecting All Animals: A Fifty-Year History of the Humane Society of the United States (Washington, DC: Humane Society Press, 2004).

${ }^{33}$ Stevens, "Laboratory Animal Welfare," 54-55; Interview of Stevens; Deborah Rudacille, The Scalpel and the Butterfly: The War between Animal Research and Animal Protection (New York: Farrar, Straus and Giroux, 2000), 101-2.

${ }^{34}$ Bart Barnes, "Roger Stevens Dies at 87; Founding Chairman of Kennedy Center,” Washington Post, 4 February 1998 , A1.
} 
Stevens served as president of the AWI and her husband was the treasurer. The Advisory Committee included Christine's father, Gesell, and two other University of Michigan scientists, Dr. Lee Dice, director of the Institute of Human Biology, and Dr. Peter Okkelberg, emeritus professor of zoology. The other members of the Committee were Dr. Eric Hansen, president of the Massachusetts Society for the Prevention of Cruelty to Animals, and David Ricardo, secretary of the British Columbia Society for the Prevention of Cruelty to Animals. In the summer of 1951, Stevens began sending out notes for a prospectus for the Institute to medical school deans, pharmaceutical companies, and others for their reaction. ${ }^{35}$

The prospectus for the AWI, which was eventually issued in printed form in October 1951, indicated that the organization had two aims: to promote the welfare of all animals and to reduce the amount of pain and fear inflicted upon animals by humans. The publication went on to say that, at present, the Institute would concern itself particularly with the issue of the use of animals in research and medicine. Arguing that humanitarians and scientists should work together, rather than being antagonists, the AWI sought to find a middle ground between what it saw as two extreme factions, those wishing to abolish animal experimentation and those who refused to acknowledge the need and responsibility for providing proper care for animals in the laboratory. Among the goals of the AWI were the establishment of a code for the handling of laboratory animals, the development of experimental techniques that would reduce the numbers of animals used and minimize their suffering, and the determination of the best methods of animal procurement that would satisfy the needs of medical research without jeopardizing "practical animal welfare." ${ }^{36}$

\section{RELATIONS BETWEEN THE NSMR AND THE AWI}

From the beginning, the NSMR took a cautious attitude toward the AWI. In June 1951, two representatives of the AWI, one a Chicago attorney, met with Carlson, Ivy, Rohweder, and several other NSMR staff members to discuss the new organization. The NSMR representatives were told that the purpose of the AWI was to improve the care of laboratory animals without hindering medical research. Upon learning that the key figures behind the AWI were Mr. and Mrs. Roger Stevens and that Mrs. Stevens' father was on the faculty at Michigan, Rohweder wrote to the dean of the Michigan Medical School. He expressed his belief that the merit of the general proposal depended "in large part upon the sincerity, honesty, and respectability of the people involved," and asked the dean to provide any information that he could which "might be able to add to our consideration of the matter." Dean A.C. Furstenberg replied that while he had no knowledge of the AWI, he could say without reservation that the Stevens were "very fine, respectable people with a high degree of professional integrity," and he believed that anything that they organized "would be for the purpose of humanitarian welfare, and initiated by an honest, sincere interest on their part." He also explained that Mrs. Stevens was the daughter of Gesell, Michigan's professor of physiology, and that she "presents the honesty and integrity which has always characterized her father." ${ }^{37}$

Rohweder then wrote to Gesell suggesting that it might be useful if he (Rohweder) could meet with Christine to discuss with her the possibility of working together to improve laboratory animal procurement and care. Rohweder mentioned that the NSMR itself had established earlier an animal care panel to work

\footnotetext{
${ }^{35}$ Christine Stevens to Raymond A. Kelser, with enclosed "Notes for a Prospectus or the Animal Welfare Institute," 30 July 1951, Box 8, NSMR Papers; various letters to NSMR, 1951, Box 8, NSMR Papers.

${ }^{36}$ The Animal Welfare Institute (New York: Animal Welfare Institute, 1951). A copy of the prospectus is in Box 9, NSMR Papers.

${ }^{37}$ Ralph A. Rohweder to A. C. Furstenberg, 29 June 1951, and Furstenberg to Rohweder, 3 July 1951, Box 8, NSMR Papers.
} 
on such issues. Gesell's reply was brief and formal, suggesting that Rohweder could arrange for a meeting with his daughter by contacting the AWI's attorney or by communicating directly with Mrs. Stevens (whose address he provided). ${ }^{38}$ Rohwder did manage to meet with the Stevens in New York in September, but he considered the meeting to be "fruitless." In a letter to a colleague, he complained that he was "Iong on suspicions about the Animal Welfare Institute and short on facts." He expressed particular concern about the Stevens' opposition to pound seizure laws and their advocacy of some kind of regulation of animal research in this country based on the British model (the 1876 Cruelty to Animals Act discussed later in this article). ${ }^{39}$

Various medical institutions began to contact the NSMR about the mail that they had received from Stevens concerning the AWI. Rohweder's replies expressed increasing suspicion of the organization as he interacted with the AWI and became more familiar with its efforts to oppose pound seizure laws. In one letter he noted that while the NSMR was being "cautiously cooperative" with the AWI, "we are quite suspicious of the true motives of the people associated with the Institute." ${ }^{\text {"I }}$ In other correspondence he voiced his theory, for which there is no evidence, that the AWI was set up by the humane societies to counter the NSMR. For example, he wrote on one occasion:

These people, who are temperamentally antivivisectionists, know that animal experimentation is necessary. Still they feel that the vicious scientists must be controlled. Further they were spurred to organize by the disruptions of their operations caused by the pound law campaign. ${ }^{41}$

In another letter written several years later, Rohweder suggested that animal breeders were helping to push the AWI agenda concerning pound animals. He pointed out that several members of the "scientific fraternity" who supported the AWI were themselves breeders of animals for profit. If animals were no longer available from pounds, then presumably laboratories would have to increase the numbers that they purchased from breeders, who would reap greater financial rewards. ${ }^{42}$

Although Rohweder's correspondence with Stevens was at first polite, and an article published in the NSMR's Bulletin was "rather non-commital, expressing a mixture of suspicion and hope," his views of the AWI became increasingly negative. ${ }^{43} \mathrm{He}$ wrote to one colleague that "the battle against the AWI and its seductively moderate propaganda line will be our big job for the next year or so at least." ${ }^{44}$ By January of 1952, NSMR leaders were expressing fear that the AWI was "an extremely dangerous new program to restrict medical research and education and pharmaceutical testing." The file copy in the NSMR archives of a letter of 8 January 1952 to the administrative secretary of the American Association for the Advancement of Science and other leaders in science has the typed name of Rohweder crossed out as sender and replaced by hand with the name of Carlson, presumably to lend greater scientific weight to the contents. This letter stated that the "apparent policy of the Animal Welfare Institute is to speak like a

\footnotetext{
${ }^{38}$ Ralph A. Rohweder to Robert Gesell, 17 July 1951, and Gesell to Rohweder, 24 July, 1951, Box 8, NSMR papers.

${ }^{39}$ Ralph A. Rohweder to George Packer Berry, 4 October 1951, Box 8, NSMR Papers.

${ }^{40}$ Ralph A. Rohweder to Albert H. MacCarthy, 26 December 1951, Box 8, NSMR Papers.

${ }^{41}$ Rohweder to Berry, 4 October 1951.

${ }^{42}$ Ralph A. Rohweder to N. R. Brewer, 2 January 1957, Box 8, NSMR Papers.

${ }^{43}$ Ralph A. Rohweder to H. C. Struck, 18 December 1951, Box 8, NSMR Papers; "New Group States Position on Animal Studies," Bull. Nat. Soc. Med. Res., 1951, 6, 8.

${ }^{44}$ Ralph A. Rohweder to Phillip S. Gelb, 1 October 1951, Box 8, NSMR Papers.
} 
champion of medical research and to act as a saboteur," citing the Institute's role in combating animal research legislation (probably pound seizure laws) in several states. The letter also charges that the AWI influenced the votes of various state legislators by political donations and, in Illinois, enlisted the support of a bloc "which represents the crime syndicate in the legislature." (An investigation of this charge in New York, however, found "no evidence of money being passed and every evidence that it was just a political favor combined with misunderstanding." ${ }^{45}$ ) Herb Brownnell, attorney for the Stevens, was accused of being the "political fixer" for the AWI, and public relations specialist Benjamin Sonnenberg was named as the person developing "sly publicity" for the organization. ${ }^{46}$ In another letter written in January 1952, Rohweder criticized what he saw as the AWl's cleverly conceived plan to oppose positive medical research legislation without seeming to be opposed to medical research. "This is an old political gimmick like the Civil Rights Congress front for the Communist Party which, of course, had no use for civil rights.."

The analogy with the Communist Party was especially charged in Cold War America and had been used before by scientists and their supporters against humane societies. For example, Anton Rost, President of the National Canine Research Foundation, compared "antivivisectionist propagandists" to Communist propagandists in a speech in 1950. Rost charged that if you offered Communists the fare to go to Russia, you would have no takers. By the same token, he suggested, you would not find any ill antivivisectionists who would be willing to forego the benefits developed through medical research on animals. A more serious charge was leveled in a 1950 editorial in the Los Angeles Times entitled "Reds and Fanatics," which reported that the "Medical Research Society" (most likely the NSMR) had discovered a "curious partnership" between "the fanatics who oppose animal experimentation for sentimental reasons" and "Communists and Communist sympathizers interested in sabatoging national defense." The editorial went on to state that:

Both at SC [University of Southern California] and UCLA, it was disclosed, medical research projects aimed at protecting the public against radioaction [sic] poisoning from atomic bombs and against germ warfare are being held up because unwanted animals are exterminated at the pound, instead of being made available for painless experimentation.

An associate dean at the University of Southern California Medical School was quoted as claiming that the Communists "must be heartened by the effect that the antivivisectionist campaigns have had in delaying the most vital national defense here," and the newspaper urged the City Council to pass an ordinance permitting pound animals that would otherwise be destroyed to be claimed for laboratory research. No evidence was cited to actually connect Communists with the campaign against the use of pound animals in research, but then it was not uncommon in McCarthy-era America for charges of Communism to be made without being accompanied by solid evidence. Thus it was implied that those who opposed the pound animal laws were unpatriotic and helping the cause of Communism, at the least, and Communists themselves in the worst case. ${ }^{48}$

Although critical of the lobbying and other "political" tactics of the AWI, Rohweder was not averse to employing such strategies himself on behalf of the agenda of the NSMR (in addition to using the "C"

\footnotetext{
${ }^{45}$ Ephraim Shorr to Ralph A. Rohweder, 4 February 1952, Box 8, NSMR Papers.

${ }^{46}$ A. J. Carlson to Howard Meyerhof, 8 January 1952, Box 8, NSMR Papers.

${ }^{47}$ Ralph A. Rohweder to Betty and William Weller, 14 January 1952, Box 8, NSMR Papers.

48 "Reds and Fanatics," Los Angeles Times, 18 April 1950, A4; “Canine Judge Praises Animal Use in Research,” Los Angeles Times, 9 August 1950, 23.
} 
word). In one letter discussing how to combat the efforts of the AWI, for example, he suggested finding ways to make public relations specialist Sonnenberg "regret the AWI account" and to neutralize "the tremendous political influence" of attorney Brownell. He also referred to the development of "promotion gimmicks" which might be used "to puncture the facade of the AWI."

In February 1952, Stevens wrote to Rohweder informing him that "garbled reports" of the Institute's aims and activities had reached her "in a roundabout way," and that it was her understanding that some of these reports had originated in his office. While saying that she respected an honest difference of opinion, she challenged Rohweder to tell her directly what statements he had been making about the AWI. In his reply, Rohweder frankly admitted that he was suspicious of the Institute, though he would welcome an opportunity to work together on constructive activities. He stated that he had changed his original thinking on the AWI and added: "I now fear that your fixed purpose is to defeat measures to expedite medical progress - and to do it behind a facade of pretended belief in medical research." He criticized what he considered to be misrepresentations in the publicity issued by the AWI and closed by saying that he would welcome Stevens "adopting a positive, responsible and honest policy regarding the procurement of dogs and cats for research." 50

The question of procurement of research animals was at the center of the controversy between humane societies and the NSMR. It was difficult to reach any kind of accommodation on this matter because the two sides were on completely different wavelengths. To Rohweder and many scientists, the opposition by the AWI and many humane groups to pound seizure laws was absurd and counterproductive. After all, the pound animals to be turned over to laboratories for research were only the "doomed" ones, those scheduled to be euthanized by the animal shelters. In one of his letters to Stevens, Rohweder asked her whether she believed "that animals should be slaughtered by the hundreds of thousands just to get rid of them and that other thousands should be specifically raised to fill research needs." ${ }^{51}$ Denying pound animals to research laboratories would hinder medical progress by making research more expensive, yet it would not save the lives of these creatures in any case.

What Rohweder and many scientists did not take into account, however, was that saving the lives of animals was not the highest goal of the humane societies. Of course, they would have preferred not to have had to put so many animals to death. But their main aim was to prevent the suffering of animals. They believed that it was better for an animal to be humanely "put to sleep" than to die in the streets from hunger or cold or to be run over by an automobile. Most of those who turned over a pet to a humane society shelter believed that they could at least be assured that the animal would die a painless and peaceful death if a home could not be found for it. Undoubtedly, many of these individuals would have been horrified to think that their pets were to be made the subject of experiments before they were put to death. As the Royal Society for the Prevention of Cruelty to Animals in Britain commented, releasing shelter animals to laboratories would break faith with the public, which gave humane societies their pets in order that they might be given a painless end. ${ }^{52}$ In addition, the humane societies must have realized that they would alienate many of their financial supporters if their shelters served as animal suppliers for laboratories. Referring to the pound law controversy in the United States, Andrew Rowan wrote in 1984:

\footnotetext{
${ }^{49}$ Ralph A. Rohweder to Phil [Gelb], 8 January 1952, Box 8, NSMR Papers.

${ }^{50}$ Christine Stevens to Ralph A. Rohweder, 18 February 1952, and Rohweder to Stevens, 26 February 1952, Box 8, NSMR Papers.

${ }^{51}$ Ralph A. Rohweder to Christine Stevens, 18 October 1951, Box 8, NSMR Papers.

${ }^{52}$ Editorial, “Aid to Antivivisectionists,” J. Am. Med. Assoc., 1953, 153, 1039.
} 
Virtually all the established humane societies in the country centered their work around the provision of shelters for homeless or lost dogs and cats. Forced surrender of these animals threatened the humane movement's basic structure, namely, a suffering-freesanctuary for animals. ${ }^{53}$

It should be noted that the AWI was not opposed to all use of pound animals in research. In 1952, the organization clearly stated that it was not opposed to voluntary agreements between animal shelters and medical institutions that made available stray animals that were unclaimed and scheduled to be destroyed for research, provided that "they are used only for those experiments in which they are first placed under full anesthesia, never permitted to recover consciousness, but pass directly into death." The AWI statement went on to further clarify its position:

It does not object to animal experimentation under properly controlled conditions, but it does object to the forced surrender of animals to laboratories, and to repeated attempts to compel humane societies to violate their ethical principles by requiring them to act as procurement agencies for experimental animals upon which physical or mental distress may be inflicted. ${ }^{54}$

The other main area of difference between the NSMR and the AWI was the question of regulation of animal research. Animal welfare advocates argued that housing and care for research animals were poor in many laboratories and that more could be done to reduce suffering in experimental procedures. The AWI favored placing some kinds of licensing and oversight restrictions on animal experimentation. Their model was the 1876 British Cruelty to Animals Act, which had regulated animal research in Britain for over a century. This law required that both facilities and investigators involved in animal research be licensed by the Home Office, which was given oversight responsibilities for animal experimentation. ${ }^{55}$ Here again there were deep philosophical differences between the AWI and the NSMR, which rejected the idea that there was a significant amount of abuse in the care and use of animals in animal laboratory research. American biomedical scientists in general were opposed to any kind of government regulation of research, and the British law was anathema to them. In their view, the law had hampered scientific research and education in Britain. In a letter to Stevens in February 1952, Rohweder responded to the AWI claim that the United States lagged behind Britain with regard to regulation of vivisection, stating:

Not if you consider the rate of medical discovery important, it doesn't. The United States is the scene of more medical research and more medical discoveries than all the other countries on earth put together. America's capacity in this regard, like America's great productive capacity, is in part due to the fact that we are not quite yet strangled with regulations, bureaucracy and red tape. Have you talked to British scientists about the extra cost and the extra effort of the extra paper work? Have you heard the stories about the "understandings" with inspectors and all of the other bureaucratic shenanigans that characterize the "control everything" type of society? ${ }^{56}$

\footnotetext{
${ }^{53}$ Rowan, Mice, Models, and Men, 53.

54 Animal Welfare Institute, “A Discussion on Procurement," Information Report, February-March, 1952, 1 (2), 1. Copy in Animal Welfare Institute, Information Report and AWI Quarterly Compilation, vol. I, 1951-1980 Washington, DC: Animal Welfare Institute, n.d.)

${ }^{55}$ For a detailed discussion of the British law, see Richard D. French, Antivivisection and Medical Science in Victorian Society (Princeton, NJ: Princeton University Press, 1975).

${ }^{56}$ Rohweder to Stevens, 26 February 1952.
} 
Stevens did visit Great Britain in the spring of 1952 and she spent a month there visiting laboratories and talking to both scientists and animal welfare advocates. In a report of her trip published in the AWl's Information Report, she praised the quarters for and treatment of animals in most laboratories and reported that many eminent British scientists to whom she spoke supported the 1876 law. She also reminded readers of the many important biological advances that had taken place in Britain during the law's tenure. Stevens also developed a close relationship with the Universities Federation for Animal Welfare, a British organization that had been founded in 1926, and its director, Major Charles W. Hume. The two groups shared similar aims. ${ }^{57}$

Historian Richard French, the author of the definitive study of the 1876 British law, has concluded that within a relatively few years of the passage of the law, the administrative arrangement that developed for its enforcement regained "an all-important degree of autonomy for the medical scientists." In 1883, decision making on applications for licenses under the law was effectively transferred from the Home Secretary to a private organization founded by scientists, the Association for the Advancement for Medical Research (AAMR). The Association almost never refused applications for licenses and largely succeeded in removing the Act's restrictions on experimental research. Although the arrangement with the AAMR was terminated in 1913, the Home Secretary continued to rely on an advisory body of scientists and physicians recommended by the Royal Society and the Royal College of Physicians and Surgeons in the enforcement of the Act. French concluded that the medical and scientific communities were generally satisfied with the administration Act from the late $1880 \mathrm{~s}$ on. ${ }^{58}$ His research showed that the number of licensees and animal experiments under the Act mushroomed over the course of the twentieth century, and he pointed out that Britain played a major role in the development of fields such as immunology and pharmacology in this period. ${ }^{59}$

There did not seem to be any room for compromise on the question of regulation any more than there was on the matter of the pound animal legislation. The AWI and other groups such as the Humane Society of the United States firmly believed that some form of regulation of animal experimentation (other than voluntary self-regulation by scientists) was necessary and that the British law had not seriously hindered biomedical research in that country. The NSMR and other scientific societies believed equally strongly that such regulation was unnecessary because they rejected the premise that there was significant abuse of laboratory animals. They were also convinced that regulation would hamper the progress of science and that the British legislation had a negative impact on research. University of Rochester physiologist Wallace Fenn, for example, informed Gesell in a letter in 1951 that: "One cannot remain long in Britain without hearing comments concerning the difficulties experienced by physiologists because of the antivivisection laws." ${ }^{60}$

The unwillingness of the biomedical community to give ground on either the pound law or regulation issues is reflected in the response given by the Federation of American Societies for Experimental Biology (FASEB), the umbrella organization for groups such as the American Physiological Society, to a request by the $\mathrm{AWI}$ in January 1952 for exhibit space at the Federation's upcoming meeting. Although the Federation allowed other exhibits relating to animal care and animal experimentation at the meeting, it

\footnotetext{
${ }^{57}$ Animal Welfare Institute, Information Report, June-July, 1952, 1 (4), 1-4. A copy of this publication is in Box 9, NSMR Papers and also in Animal Welfare Institute, Information Report and AWI Quarterly Compilation; Interview of Stevens.

${ }^{58}$ French, Antivivisection, 200-19.

${ }^{59}$ Ibid., 392-405.

${ }^{60}$ Wallace O. Fenn to Robert Gesell, 28 November 1951, Gesell file, AWI Files.
} 
turned down the request from the AWI. The reply to Stevens outlined the rationale for FASEB's denial of exhibit space to the AWI:

May I say frankly that the reason for refusing your request was the serious misgiving that the Federation Executive Committee has regarding the fundamental attitudes of the Animal Welfare Institute. The Federation is unequivocal in its points of view and is not interested in any compromise position. For example, it would unreservedly back an animal pound bill in the New York Legislature similar to that introduced last year. It is entirely opposed to legislation patterned after the present laws in England. The issues are straightforward; the Federation comprises a large proportion of investigators who are vitally concerned; it knows precisely what these biologists want and it knows that these desires are eminently sensible and sound. ${ }^{61}$

In one particularly virulent attack on the animal welfare groups advocating some form of control over animal experimentation, University of Minnesota physiology professor Maurice Visscher charged that "kindness to animals as a fetish becomes the camouflage for some of the worst misanthropes of our civilization." He went on to add:

The new twist to the antivivisection campaign is an emphasis on "regulation" rather than "abolition." American antivivisectionists point to the long history of government regulation of animal experimentation in Great Britain and ask when the U.S.A. will imitate this "advanced" humanitarianism. They do not, of course, add that much of Britain's difficulty of training medical students in surgery comes from these laws; that British scientists have had to go to other countries to make certain important studies; that the great humanitarian Adolf Hitler also put through a similar decree.

\section{GESELL AND THE PHYSIOLOGISTS}

Visscher had already expressed some concern about a published statement by Gesell as early as 1951. Gesell's concern about animal welfare was part of a broader philosophical outlook related to the welfare of man and animals. In 1951, he published a lecture that he had been giving annually to medical students in his physiology course at Michigan. The work appeared in a periodical called The Diplomate, which was published by the National Board of Medical Examiners of the United States. In the lecture, Gesell expressed his view that man was the "greatest biological menace" because of his waste and destruction of natural resources and his ingenuity in fashioning lethal weapons. He was also concerned about the problem of overpopulation by humans, which he saw as eventually leading to famine, social unrest, and ecological disaster, as well as a cheapening and degradation of humanity. By focusing so heavily on the saving of lives, modern medicine has inadvertently contributed to this problem. Gesell believed that the physician had a special responsibility as a guardian of the human race and had to make mankind as a whole, as well as man as an individual, the province of medicine. ${ }^{63}$

Gesell concluded that greater humanity was essential to survival. In his view, the road to humanity involved kindly feelings for all creatures and intelligent discrimination between cruelty and kindness. As part of his discussion of the population problem, Gesell pointed out that if the population of the United

\footnotetext{
${ }^{61}$ Copy of letter from FASEB to Christine Stevens, 25 January 1952, reproduced in printed memo from Robert Gesell to members of FASEB, 25 February 1952. Copies of Gesell's memo are in Box 8, NSMR Papers, and Box 2, Physiology Papers.

${ }^{62}$ Maurice B. Visscher, “Antivivisection 1954 Version,” Bull. Nat. Soc. Med. Res., 1954, 4, 13.

${ }^{63}$ Robert Gesell, “Some Biological Aspects of Medicine,” The Diplomate, 1951, 23, 131-43.
} 
States doubled, it would be necessary to double the number of animals to be "raised and slaughtered" for the sustenance of the additional people (apparently he did not think of vegetarianism as a solution). The passage that alarmed Visscher, however, involved Gesell's comment that in a population increase of ten million, "five per cent of these unfortunates, or 500,000, would be doomed to the dread disease of cancer." He went on to add: "In the meantime, countless animals will be subjected to painful experimental investigation for the eradication of cancer." ${ }^{, 4}$

Visscher wrote to Gesell that he agreed with his views about overpopulation, but that he was concerned about Gesell's statement on animals being subjected to painful experimentation. He thought that this sentence would be used out of context "by our antivivisectionist friends," as evidence that Gesell did not believe that the experimental investigations in question were justified. He advised Gesell:

It occurs to me that it might be a desirable thing for you to put on record, for example in the Bulletin of the National Society for Medical Research, a positive statement which could be useful in case the antivivisectionists attempt to make capital out of the fact that a professor of physiology has said something which could be construed to be a blanket criticism. $^{65}$

Gesell regretted that his remarks on cancer did not meet with Visscher's approval, but he declined to accept his suggestion. Instead, he sent Visscher a copy of his 1946 letter to Carlson, previously cited, in which he had expressed his view that the present conditions of animal experimentation were not ideal. He also quoted one of Webster's definitions of humanity, which referred to the kind feelings and dispositions of man, "especially a disposition to relieve distress and to treat all creatures with kindness." 66

Early in 1952, Rohweder tried to set up a meeting to discuss the AWI with Gesell, but the physiologist indicated that he would rather talk with the NSMR president Carlson, perhaps because the latter was a fellow physiologist. Carlson wrote to Gesell that he was willing to meet with him, but also asked him why he refused to meet with Rohweder, who Carlson described as "a man of ability, industry and integrity," a judgment that he believed was shared by most medical school deans. ${ }^{67}$ It is not clear whether the proposed meeting between the two physiologists ever took place, but at the same time the NSMR held a planning meeting in New York with representatives of various scientific societies and pharmaceutical companies to "develop a sound policy and an effective action program" in relation to the AWI. ${ }^{68}$

Gesell was obviously becoming frustrated with the NSMR and its harsh criticisms of the AWI. It is possible that the refusal of FASEB in January 1952 to allow the AWI to exhibit at its upcoming meeting was the last straw. In February 1952, he sent a long, printed memo to all members of FASEB. The communication expressed his concerns about animal experimentation. He reproduced an article and two letters published in the 6 August 1949 issue of the British medical journal Lancet that criticized certain studies published in American and Canadian medical journals for inflicting unnecessary and unjustifiable pain on the experimental animals involved. Gesell also mentioned a more recent study involving the drowning of 160 dogs and charged that all of these experiments "remind us so inescapably of the 'Doctors of Infamy' (Henry Schuman, New York), who performed terminal experiments on men and women without the use of

\footnotetext{
${ }^{64}$ Gesell, "Some Biological Aspects," 140-41.

${ }^{65}$ Maurice B. Visscher to Robert Gesell, 15 May 1951, Box 2, Physiology Papers.

${ }^{66}$ Robert Gesell to Maurice B. Visscher, 22 May 1951, Box 2, Physiology Papers.

${ }^{67}$ Ralph A. Rohweder to Robert Gesell, 9 January 1952, Ralph A. Rohweder to Lee R. Dice, 12 January 1952, and A. J. Carlson to Robert Gesell, 15 January 1952, Box 8, NSMR Papers.

${ }^{68}$ Ralph A. Rohweder to A. J. Carlson and A. C. Ivy, 17 January 1952, Box 8, NSMR Papers.
} 
anesthesia." In relating these experiments to Nazi atrocities, Gesell was using a tactic similar to that used by the defenders of animal research when they alluded to Hitler and to the Communist Party in their criticisms of the AWI. Gesell also defended the goals of the organization headed by his daughter, noting that the "conservative position" of the AWI "has been attacked from both sides with a fanaticism less becoming the medical sciences than the anti-vivisectionists who are allegedly guided by sentiment alone." ${ }^{69}$

Gesell's letter was followed by his statement at the business meeting of the American Physiological Society (APS) on 15 April 1952, referred to at the beginning of this article. In expressing concern about some of the types of animal experiments being carried out, Gesell devoted most of his effort to criticizing the NSMR. According to Gesell, the NSMR would have people believe that the important issue was vivisection against antivivisection. But that was not the issue, because, to a physiologist, there can be no question about vivisection per se. The real issue, he argued, was humanity versus inhumanity. For the NSMR, antivivisection was an "indispensable bogie which must be kept before the public at all costs." They attached "a stigma of antivivisection to any semblance of humanity" and used this technique in attacking animal welfare groups such as the American Humane Society (and Gesell also undoubtedly had in mind the AWI as well). He concluded with: "This may well be the blackest spot in the history of medical science." ${ }^{70}$

Visscher later commented about Gesell's presentation at the meeting: "As might be expected, his ideas did not receive a very warm reception from his scientific colleagues." ${ }^{71}$ In fact, Gesell barely escaped a vote of censure at the business meeting. ${ }^{72}$ The matter was referred to a committee of three pastpresidents of the APS (including Visscher), who met with Gesell for several hours to discuss his concerns. Apparently at some point in the meeting, Visscher made a comment to the effect that there could be no cruelty in the pursuit of knowledge, a remark that Gesell found shocking. ${ }^{73}$

Gesell's colleagues were not quite sure what to make of his remarks or how to deal with them. In the months following the meeting, Gesell's actions were described as a "tragedy", a "distressing problem," and a "calamity" by his colleagues. ${ }^{74} \mathrm{He}$ was seen by one colleague as having made a "clear break with science." ${ }^{75}$ Another complained that Gesell's comments "will probably cause us more trouble than any statements made by anyone in the twentieth century."76 His views were called "misguided," "extreme," "absurd," and "hysterical." ${ }^{, 7}$ Apparently, even his colleagues at Michigan were not in sympathy with his

\footnotetext{
${ }^{69}$ Robert Gesell to members of FASEB, 25 February 1952, Box 2, Physiology Papers.

${ }^{70}$ Gesell to members of FASEB, 10 March 1953.

${ }^{71}$ Maurice B. Visscher, “A Half Century in Science and Society,” Ann. Rev. Physiol., 1969, 31, 1-18.

${ }^{72}$ Robert Gesell to Owen Gibbs, 6 November 1952, Box 2, Physiology Papers.

${ }^{73}$ Visscher, "A Half Century," 10; Robert Gesell to Wallace O. Fenn, 1 December 1952, and typescript marked "confidential" summarizing a meeting with Gesell at the 1953 International Physiological Congress, Gesell file, AWI Files; Robert Gesell to Maurice B. Visscher, 27 May 1953, Box 2, Physiology Papers.

${ }^{74}$ Eugene M. Landis to A. J. Carlson, 23 March 1953, Carlson to Landis, 24 March 1953, and R. W. Gerard to Landis, 1 June 1953, Box 8, NSMR Papers.

${ }^{75}$ Eugene M. Landis to Ralph A. Rohweder, 22 May 1953, Box 8, NSMR papers.

${ }^{76}$ Hal Kome to R. J. Main, 8 June 1953, Box 8, NSMR Papers.

77 Eugene M. Landis to A. J. Carlson, 27 March 1953, and Carlson to Paul C. Busy, 17 March 1953, Box 8, NSMR Papers; Landis to Carlson, 23 March 1953.
} 
views. ${ }^{78}$ To make matters worse, Gesell sent out another mail to FASEB members in March 1953 in which he reproduced his remarks from the meeting and again attacked the NSMR. Also troubling his fellow scientists was the fact that his remarks were being used by the National Anti-Vivisection Society as evidence that at least one prominent biomedical researcher was concerned about how animals were being used in experimentation. ${ }^{79}$

Finding it hard to believe that a physiologist who himself had made use of many animals in teaching and research could make such charges, some of his colleagues apparently thought that some health problem had clouded his judgment. Rohweder noted that Gesell had suffered a stroke some years earlier, at around the time (according to Rohweder) where he began to take an interest in animal welfare. He could only assume that Gesell "had developed an obsession of some order." Eugene Landis of Harvard expressed his conviction, based on conversations with Gesell, that the Michigan physiologist was not well. $^{80}$

Physiologists were uncertain about how to react to Gesell's oral and written statements. Was it better to ignore his communications or to take some action, and, if so, what type of action? Carlson did send out a letter to all FASEB members attempting to refute Gesell's charges. ${ }^{81}$ The officers of the APS considered taking some disciplinary action against Gesell, including possible expulsion from the Society. It was deemed, however, that this was not advisable, given that Gesell was a senior member of APS and taking into account his apparent "illness." It was also believed that expelling Gesell from the Society might seem to make him a martyr. ${ }^{82}$ In the end, no disciplinary action was taken, and, in a possible attempt to defuse the situation, a committee was appointed to look into Gesell's charges and make recommendations. The committee consisted of John Haldi, a former student of Gesell, Horace Davenport of the University of Utah, William Ferguson Hamilton of the University of Georgia, and Hiram Essex of the Mayo Foundation, the president-elect of APS, as committee Chair. ${ }^{83}$

At the International Physiological Congress held in Montreal from 31 August to 5 September 1953, a meeting was arranged between Haldi and Gesell. Haldi and Essex also had lunch with Gesell at the Congress to further discuss the issue. Haldi and Essex agreed that the APS should adopt some sort of ethical code concerning animal research, but they were strongly opposed to any outside regulations "or anything British." ${ }^{84}$ What the ultimate consequences of these efforts to mend fences between Gesell and the APS would have been is uncertain, because Gesell died suddenly of a stroke in April 1954. His death

\footnotetext{
${ }^{78}$ A. C. Furstenberg to Ralph E. Rohweder, 28 May 1953, Box 11, NSMR Papers; Rohweder to T. B. O’Dell, 2 May 1953, Box 8, NSMR Papers.

${ }^{79}$ Gesell to FASEB members, 10 March 1953; Furstenberg to Rohweder, 28 May 1953; Rohweder to O'Dell, 2 May 1953. Gesell's statement delivered at the 1952 FASEB meeting was also published in the March 1953 issue of The National Humane Review, 15.

${ }^{80}$ Rohweder to O’Dell, 2 May 1953; Landis to Carlson, 27 March 1953.

${ }^{81}$ A. J. Carlson to members of FASEB, 17 September 1952, Box 8, NSMR Papers.

${ }^{82}$ Rohweder to O’Dell, 3 May 1953; Landis to Carlson, 27 March 1953.

${ }^{83}$ One-page typescript labeled “Committee of the Physiological Society which is looking into Dr. Gesell's charges and making recommendations," Gesell file, AWI Files.

${ }^{84}$ Typescript marked “confidential” summarizing meeting with Gesell at International Physiological Congress, Gesell file, AWI Files.
} 
was not mourned by everyone, as evidenced by Visscher's uncharitable reference to him at the 1955 APS meeting as "the late unlamented Gesell."

\section{EPILOGUE}

The animosity between the NSMR and the AWI did not end with Gesell's death. The two organizations continued to spar over questions of animal welfare and animal research. In a letter written in August 1957, Rohweder noted that "Christine [Stevens] and I are old enemies," and chauvinistically added: "Still I'll concede that she is pretty." 86 The membership of antivivisection and animal welfare groups had traditionally been dominated by women, who had often been dismissed by those in the medical and scientific establishment as ill-informed sentimentalists, and one suspects that Rohweder and some of his colleagues were not completely free of this bias. ${ }^{87}$ Rohweder's conviction that "almost without exception Jaycees are contemptuous of the antivivisectionists," referred to earlier in this article, may perhaps have been based in part on the fact that the Jaycees were a male-only organization at the time. Women were not admitted into the organization until $1984 .^{88}$

Rohweder also tended to use terms such as "fanaticism," "emotional dogmatism," "neurotically," and "she feels about the same as other antivivisectionists" (although she knows intellectually that animal research is necessary) in describing Stevens and her activities. ${ }^{89}$ In a similar vein, Carlson expressed the view that the AWI leaders "feel a strong emotional opposition to animal investigations." 90 This language is consistent with earlier criticisms of the antivivisection movement as dominated by women, whose excessive sentimentality, emotionality, and impulsiveness were seen as the causes of their "misguided" opposition to animal experimentation. ${ }^{91}$ Recall also the desire of the founders of the NSMR, referred to earlier in this article, to make sure that their organization had a "virile" name. ${ }^{92}$

In the same 1957 letter noted earlier, Rohweder labeled the AWI as "a neo-vivisectionist group" and as less of an association than "a corporate front for the personal activities of Christine Stevens." people made efforts to end the hostility between the two groups and their administrators. Rohweder acknowledged this fact when he wrote to Stevens in 1960: "As you know, quite a few people feel we should be able to reconcile our differences and work together for the dual objectives of better and more

\footnotetext{
${ }^{85}$ Bean, "Some Reminiscences (Continued)," 9.

${ }^{86}$ Ralph A. Rohweder to Steven Spencer, 23 August 1957, Box 8, NSMR Papers.

${ }^{87}$ See, for example, Susan E. Lederer, "Moral Sensibility and Medical Science: Gender, Animal Experimentation, and the Doctor-Patient Relationship," in The Empathic Practitioner: Empathy, Gender, and Medicine, ed. Ellen Singer More and Maureen A. Milligan (New Brunswick, NJ: Rutgers University Press, 1994), 59-73; Mary Ann Elston, "Women and Antivivisection in Victorian England, 1870-1900," in Vivisection in Historical Perspective, ed. Nicolaas A. Rupke (London: Routledge, 1987), 259-94; Carla Bittel, "Science, Suffrage, and Experimentation: Mary Putnam Jacobi and the Controversy over Vivisection in Late Nineteenth-Century America,” Bull. Hist. Med., 2005, 79, 664-94.

${ }^{88}$ Rohweder to Ivy, 8 September 1949. On the history of the Jaycees, see John W. Clark, A Legacy of Leadership: The U. S. Junior Chamber of Commerce Celebrates 75 Years (Tulsa, OK: U.S. Junior Chamber of Commerce, 1995).

${ }^{89}$ Ralph A. Rohweder to C. D. Thayer, 7 February 1958, Box 11; Rohweder to Alfred F. Borg, 11 December 1958, Box 8; Rohweder to A. J. Carlson, Maurice B. Visscher, and Ralph W. Gerard, 31 August 1955, Box 8; all NSMR Papers.

${ }^{90}$ A. J. Carlson to Charles K. King, 8 January 1952, Box 8, NSMR Papers.

${ }^{91}$ Lederer, "Moral Sensibility;" Elston, "Women and Anti-vivisection;” Bittel, "Science."

${ }^{92}$ Carlson and Ivy to members of Temporary Organizing Board of Directors, 26 December 1945, Box 1, NSMR Papers.

${ }^{93}$ Rohweder to Spencer, 23 August 1957, Box 8, NSMR Papers.
} 
humane animal experimentation." He added, however, that probably neither of them had much hope for broad agreement. Rohweder noted that there were many old scars and admitted that in the past he had "made mistakes that allowed misunderstandings to develop." On the other hand, he reminded Stevens that her "warm benevolence has not been focused in this direction very often either." 94

Nothing positive seems to have come from these efforts to end the animosity between the two organizations. Rohweder resigned as executive secretary of NSMR at the time the Society moved its headquarters from Chicago to Washington, D.C. in 1966. Correspondence in the NSMR files suggests that Rohweder did not part with the NSMR on completely happy terms. He did, however, reach a settlement agreement with the organization on a severance package.$^{95}$ In the 1970 s, the NSMR began to flounder and was criticized by some within the biomedical community for ineffective strategies. The Association for Biomedical Research, which had been founded in 1979, amalgamated with what was left of NSMR to form the National Association for Biomedical Research in $1985 .{ }^{96}$ As for Stevens, who was once dubbed the "duchess of the defenseless" by a reporter, she continued to serve as the president of the AWI until her death in 2002. ${ }^{97}$ The activities of the AWI, which now has 20,000 members and is headquartered in Washington, D.C., broadened over time well beyond the issue of animal experimentation to include concerns related to the welfare of farm animals and animals in the wild.

It should be noted that not all scientists considered Stevens to be an enemy. For example, pharmacologist Chauncey Leake of Ohio State University complimented Stevens for the leadership role she had played in the improvement of animal care. University of Pennsylvania physician I. B. Ravdin acceded to Stevens' request to inspect the institution's animal quarters, and he reported that she "came, and I must say, gave us no trouble." He found her to be a charming woman and was convinced that she was not an antivivisectionist. He also warned against the danger of labeling everyone with whom one has a difference of opinion as an antivivisectionist. ${ }^{98}$

Certainly, antivivisectionist organizations did not consider the AWI to be one of them. Stevens herself was clearly not an antivivisectionist. The National Anti-Vivisection Society was willing to work with the AWI where possible, but noted that there were many areas in which the two groups could not agree. They saw Stevens as being naive and inexperienced in thinking she could work together with the scientific community. ${ }^{99}$

In the same year her old adversary, Rohweder, resigned his position at the NSMR, Stevens had the satisfaction of seeing the passage of the Laboratory Animal Welfare Act of 1966. Stevens and the AWI played a significant role in promoting the Act, although it may have been an article in Life exposing the way dogs were abused by many animal dealers that finally stimulated Congress to act. Although the bill

\footnotetext{
${ }^{94}$ Ralph A. Rohweder to Christine Stevens, 10 November 1960, Box 8, NSMR Papers.

${ }^{95}$ Ralph A. Rohweder to Board of Directors, NSMR, 3 November 1966; H. E. Kingman, Jr. to Paul Brewer, 7 April 1967 ; Ralph A. Rohweder to W. T. S. Thorp, 9 February 1966; and 3-page typescript labeled "Release", 25 ovember 1966; all in Box 5, NSMR Papers.

${ }^{96}$ F. Barbara Orlans, In the Name of Science: Issues in Responsible Animal Experimentation (Oxford: Oxford University Press, 1993), 46-47; Rudacille, Scalpel and Butterfly, 170.

${ }^{97}$ For biographical information on Stevens, see Adam Bernstein, "Christine Stevens Dies: Animal Rights Activist," Washington Post, 11 October 2002, B6; “The Animals' Angel: Celebrating Christine Stevens' Passionate Animal Activism,” AWI Quarterly, 2003, 52, 8-9.

${ }^{98}$ Chauncey D. Leake to Christine Stevens, 8 January 1962; I. S. Ravdin to N. R. Brewer, 24 June 1959; both in Box 8, NSMR Papers.

${ }^{99}$ Ward Caille, "National Society's Report on New Animal Welfare Institute,” Bull. Nat. Anti-vivisection Soc., 1952, 1, 1-4.
} 
did not actually regulate experimentation itself, it did empower the Secretary of Agriculture to set standards for the humane care and housing of animals on the premises of animal dealers, in transit, and in the laboratories of scientific institutions.

Amendments to the Act and other legislation and regulations over the past few decades have further refined these standards and made experimental procedures involving many animals subject to law. For example, research facilities must establish institutional animal care and use committees to review and approve research protocols for animal experiments involving covered species. The original law also applied only to dogs, cats, nonhuman primates, rabbits, hamsters, and guinea pigs, but the list of animals covered was later expanded to include all warm-blooded animals. Mice, rats, and birds, which make up the great majority of animals used in research, were originally covered under the provisions of the expanded law, but then Senator Jesse Helms amended the Senate's version of the 2002 farm bill to specifically exclude these groups from the protection of the Animal Welfare Act. As for the pound laws that created such conflict between the AWI and the NSMR, these largely became irrelevant as scientists increasingly made use of animals bred specifically for research in their experimental work. ${ }^{100}$

The controversy over the use of animals in experimentation has of course not disappeared. Some animal advocates believe that the earlier-mentioned regulations do not go far enough, and some scientists consider them to be a burdensome nuisance. Since the rise of the animal rights movement in the 1970s, the question of animal experimentation, along with other uses of animals, has increasingly captured the public's attention. Strong supporters of animal rights go well beyond the reforms sought by animal welfare groups, such as the Animal Welfare Institute, calling for an end to the use of animals in research, for entertainment purposes, and as sources of food and other products. ${ }^{101}$ The interest in finding alternatives to the use of animals, as well as ways to reduce their numbers and suffering, in biological and medical research, advocated by Gesell as early as the 1940s, has drawn increasing interest among scientists and animal welfare advocates. ${ }^{102}$ However, eliminating the use of animals in biomedical research and testing appears to be a long way off, if it is ever possible to achieve. The debate over how to balance the welfare of animals versus the need for them in biomedical research is thus likely to continue far into the future.

\footnotetext{
${ }^{100}$ Stevens, "Laboratory Animal Welfare;" Rowan, Mice, Models, and Men, 54-57; Rudacille, Scalpel and Butterfly, 127-30; Orlans, In the Name of Science, 44-60; Unti, Protecting, 70-81.

${ }^{101}$ On the history of the animal rights movement, see James M. Jasper and Dorothy Nelkin, The Animal Rights Crusade: The Growth of a Moral Protest (New York: The Free Press, 1992); Harold D. Guither, Animal Rights: History and Scope of a Radical Social Movement (Carbondale: Southern Illinois University Press, 1998).

102 Parascandola, "Historical Perspectives."
} 